\title{
ISSN 0853-5884
}

\section{JURNAL PENELITIAN PERIKANAN INDONESIA}

The descriptors given are free terms. This abstrac sheet may be reproduced without permission or charge

J.Lit.Perikan.Ind. 12 (2) 2005: p. 1-7

Purnomo, K (RIFSE)

Kartamihardja, E.S. (RCCF)

The total fish catch of Wonogiri reservoir (6.480 ha) in $1998-2000$ range from 3300.8 to 3510.0 ton per year. The Java barb (Barbodes gonionotus) being one of the five major commercially important species in the reservoir, constitutes about 1.390 ton or $40 \%$ of the total catch. Studi on the growth, mortality, and feeding habits of java barb was conducted in Wonogiri reservoir from January to December 2000 . The objective of the study is to provide information, relevant to the management of Java barb in the reservoir. The vcri Bertalanffy growth parameters and mortality rate were estimated from length frequency data using FISAT program. The growth performance index ( $\left.\Phi^{\prime}\right)$ was computed from the equation of Pauly \& Munro's (1984). Analysis of the stomach contents was carried out to evaluate their feeding preferences. Results show that the total length of individuals of java barb ranged from: 11.0 to $39.0 \mathrm{~cm}$, and the weight from 20.0 to $1100.0 \mathrm{~g}$. The length-weight regression both for males $(b=2.938 \pm 0.084)$ and females $(b=3.008 \pm 0.041)$ indicated isometric growth. The overall sex ratio was $1: 2$ in favour of females. The von Bertalanffy growth parameters for the sexes combined were: $L_{\infty}=47.3 \mathrm{~cm}$ total length; $k=0.42$ year $^{-1}$; and the $\Phi^{\prime}$ (phi-prime) estimation was 2.973 . Natural mortality rate, $M$, was 0.89 year $^{-1}$, fishing mortality $(F)$ was 0.17 year $^{-1}$ and the total mortality rate $(Z)$ was 1.06 year $^{-1}$ (range from $0.93-1.19)$ and the exploitation rate $(E)$ was 0.16 . The diets of java barb composed of macrophytes $(80.41 \pm 1.27 \%)$, detritus $(12.17 \pm 0.95 \%)$ and phytoplankton $(7.43 \pm 1.01 \%)$. It indicates that the java barb is herbivorous species. Although the java barb stock was exploited below the optimum level the fisheries manager should recommend the fisher to take greater responsibility for the sustainability and conservation of the fisheries resources.

J.Lit.Perik .n.Ind. 12 (2) 2005: p. 9-27

Utomo, A.D. (RIIWF)

Prasetyo D. (RIIWF)

Barito River have economics value in fisheries, many fishes are living there and it's habitats for fishing, so that ecosystem snould be managed properly. The objectives of the study was to reach fishing gear selectivity of length, fishing mortality of some fishes, catches data and fishing season of some main fishing gears. The research was conducted by survey methods on Mei 2003 to December 2003. Two types of locatian were selected; the first location at Danau Panggang District (South K.alimantan) there are many fishing activities, and the secound location at Rantau Birit, Jenemas District (Central Kalimantan) that location have strongly changing ecosystem. Data were collected by sampling methods and distributed questioner blank sileets to fisnerment. Catches and selectivity data were analised using data tabulation and histogram grafik, growth and mortality parameter were analised by FISAT II program. The result shawed that catches data at Rantau Birit, Jenemas Distrik (Central Kalimantan) lower than some location at
Danau Panggang Distrik (South Kalimantan). Main fishing gear: hampang (barrier with traps chamber), selambau (filtering net), beje (seine with pond traps), mangumpe (seine with fish aggregating device) are not selectived gears for big fish such as baung (Mystus nemurus) and haruan (Channa striatus), that device caught young fish before doing reproduction. The explotation rate $(E)=0.71$ for baung (Mystus nemurus), $\mathrm{E}=0.57$ for haruan (Channa striatus) and $\mathrm{E}=0.41$ for sepat siam (Trichogaster pectoralis).

J.Lit.Perikan.Ind. 12 (2) 2005: p. 29-37

Nasution, S.H. (P2 Limnologi-LIP!)

Activity of the fishery tending to exploit natural sources and condition of the water quality changing or polluted, would result the decreasing the amount of fish populations in nature. Particularly if a number of the species exploited is endemic which needed to protect and threatened species. Rainbow selebensis fish (Telmatherina celebensis Boulenger) including into set of Telmatherinidae family and is one of endemic fish in Lake Towuti. The currant research aims to know the characteristic reproduction this endemic fish, as basic data to the effort conservation and domestication. The results show that testis and fish ovary are found one organ during a period of gonad development. Gonad maturity stage. The range of eggs diameters is $0.02-1.79 \mathrm{~mm}$ with $103.2 \mathrm{~mm}$ maximum length. Male and female fishes are mature at size of 74.3 and 77.3 $\mathrm{mm}$ total ler.gth respectively. Gonad maturity index value of male and female is $0.46-0.81 \%$ and 1.87 $2.65 \%$. The reproduction ability is in relation to the eggs produced, so that it affects on amount of juveniles. The range of fish fecundity is $185-1,448$ eggs with $63.9-88.6 \mathrm{~mm}$ total length and $2.756-9.600$ $\mathrm{mg}$ total weight.

J.Lit.Perikan.Ind. 12 (2) 2005: p. 39-45

Suprapto (RIMF)

Sumiono, B. (RIMF)

Hendriyatna, N. (RIMF)

Study on community structure of macrozoobenthos was conducted in Province Sumatera Utara waters (Malaka Strait) at September 2003 by sampling in selected twelve siations. Sampling of substrates was conducted by using Grab Sottom Sampler. The objective of the study is to gather information on species composition, density, diversity indexes, and some parameters of bottom water quality. Results show that the number of species of macrozoobentos collected were 36 species of phylum Mollusca, Annelida, Arthropoda, and Echinodermata. Diversity of total macrozoobentos varied from $3,8 \times 10^{3}-7, i \times 10^{5}$ ind $\mathrm{m}^{-2}$. Diversity index is low-grade $\left(H^{\prime}=1.77\right)$ its indicating a polluted condition. Average level of evenness indexces was 0.77 . The most abundances of macrozoobentos species were Tellina sp., Epicodakia sp., Dentalium sp., Turitella sp., and Plicarcularia sp. The average levels of temperature and salinity were $29.13^{\circ} \mathrm{C}$ and 32.83 ppt respectively. Range level of current velocity was $0.05-0,53 \mathrm{~m} \mathrm{dt}^{-1}$ and type of bottom substrat was dominated by fine sands and silt. 
J.Lit.Perikan.Ind. 12 (2) 2005: p. 47-56

Hariati, T. (RIMF)

Taufik, M. (RIMF)

Zamroni, A. (RIMF)

A research on reproduction of round scad (Decapterus russelli) and Indian mackerel (Rastrelliger kanagurta) from the Straits of Malacca, part of Indonesia aims to estimate the spawning season and area, and the length at first maturity $\left(\mathrm{I}_{\mathrm{m}}\right)$ of both scad and indian mackerel stock. The result was expected to be used as a basic for management of the stock. The samples of round scad and mackerel of medium to big size $(15 \mathrm{~cm}$ and more) 1,000 fish for each species were collected by month during the period of May 2003-December 2004 from the catch of purse seine flest landed in Tanjung Balai, North Sumatera Province. The monthly observations were emphasized on body length and weight measurement, maturity, and weight of gonad of the female, in order to get the values of percentage of maturity and gonad index as well as $\mathrm{I}_{\mathrm{m}}$ values. The results show that spawning season for the round scad occurred from April to October, while the mackerel occurred from May to October and from December to March. Spawning area of both species was estimated in the northern part of the Malacca Straits, around 200 meters isodepth line. The values of $L_{m}$ of round scad and indian mackerel are $16 \mathrm{~cm} \mathrm{FL}$ and $17 \mathrm{~cm} \mathrm{FL}$, respectively.

J.Lit.Perikan.Ind. 12 (2) 2005: p. 57-67

Hariati, T. (RIMF)

The exploitation rate of both indian scad (Decapterus russelli) and indian mackerel (Rastrelliger kanagurta) caught using Sibolga's purse seine in west Sumatera waters in 1995 were high, 0.65 and 0.75 respectively. CPUE per vessel per day of scads and mackerels in the five fishing grounds tended to decrease. Several Sibolga purse seiners tried to find new fishing grounds along west Sumatera coast through Banda Aceh waters. A research on purse seine fishery of Sibolga was conducted in the period of 2003-2004, to get some information on the status and it's development. Catch and effort data were collected from a private landing place, dimension of vessels, operational aspects, and lengths of several dominant pelagic species were obtained by interview and measurement. In 2003, the development of vessels size, number of vessels, and the use of rumpon beside halogen lamps had made two kinds of purse seine net i.e. the 1 inch and the 3-4 inch of purse seines, and also the extention of fishing grounds to the waters off the shelf (deeper sea). Fishes caught by the 1 inch purse seine were dominated by the three scads (D.russelli, $D$. macrosoma, and D. macarellus) while by the 3-4 inch were dominated by skipjack (Katsuwonus pelamis), tuna (Thunnus albacares), as weil as little tunas (Auxis thazard and Thunnus tonggo/). Both range of the length and $\mathrm{I}_{\mathrm{c}}$ value of scads, indian mackere (Rastrelliger kanagurta) and bigeye scad (Selar crumenophthalmus) caught by the 1 inch purse seine in 2003 were wide and high expecially indian mackerel, since the development of fishing grounds into the deeper waters probably close to the spawning ground.
J.Lit.Perikan.Ind. 12 (2) 2005: p. 69-74

Suman, A. (RIMF)

Boer, M. (BAI)

The objective of this research is to study the population dynamic aspects of endeavour shrimp ( $M$. ensis de Haan) in Cilacap and adjacent waters. This research was conducted from May 2001 to April 2002 with survey method. Results show that the size at first maturity of endeavour shrimp ( $M$. ensis de Haan) was $31.8 \mathrm{~mm}$ in carapace length and spawned throughout the year with the peak spawning season in September. The von Bertalanffy growth equation of male endeavour shrimp is $L t=41,5\left[1-\mathrm{e}^{-1,49(t+0,03)}\right]$ and female is $L t=52,2\left[1-e^{-1,52(t+0,023)}\right]$.

J.Lit.Perikan.Ind. 12 (2) 2005: p. 75-82

Suman, A. (RIMF)

Study on the status of exploitation to endeavour shrimp (Metapenaeus ensis de Haan) resources in Cilacap and adjacent weters needs to be done for its management purpose. The objective of this research is to analysest the exploitation status of endeavour shrimp rescurces in Cilacap and its adjacent waters. This research was conducted from December 2002 to June 2003. The evaluation was based on the surplus production and bioeconomic models. Results show that the annual production average of endeavour strimp in Cilacap and adjacent waters landed about $77 \%$ in Cilacap District, $21 \%$ in Ciamis District,and 2\% in Kebumen District. Maximum sustainable yield of endeavour shrimp in Cilacap and adjacent waters is 540 ton per year and effort optimum is about 305 units of fishing gear standard (aciive trammel net in weekly trip). Status of its open access exploitation stayed at 413 ton production level per year with 509 units effort of standard gear, thus the condition of optimal exploitation stayed at 206 ton per year with 365 unit effort of standard gear. For sustainable exploitation, it needs to be restricted for $\mathbf{3 0 5}$ units effort of standard gear per year and 540 ton production per year.

J.Lit.Perikan.Ind. 12 (2) 2005: p. 83-93

Hartati, S.T. (RIMF)

Edrus, i.N. (BPTP, Maluku)

The reefs of Saleh Bay v'ere in serious degradation occurring in across the islands, included Rakiti and Taikabo. The need of baseline data may upsurge in regarding of rehabilitation program for the this bay. One of variables needed to evaluate and monitor the changing coastal water environment is coral fish. Coral fish is a suitable indikator of unsettled coral habitats. Hence, this study identified the intrinsic species and some indeces including the fish diversity index $(H)$, dominance index (D or Simpson), evenness index (E), and fish density $\left(\mathrm{m}^{2}\right)$. The method used in data gathering was a census visual transect. The results show that total coral fish kinds found in the study areas was 105 species, variying from 34 to 57 species for respective transect sites. Fish density varied as well, from 3.4 to 17.7 ind $\mathrm{m}^{-2}$. Fish diversity indeces (H) were low level for the whole transect sites and ranged from 2.54 to 3 . Dominance or Simpson indeces for the respective-transect sites ranged from 0.08 to 0.14 , whereas evenness indeces ranged from 0.72 to 0.75 . It means that there are no population dominance and significant dissilution in the coral fish community. 

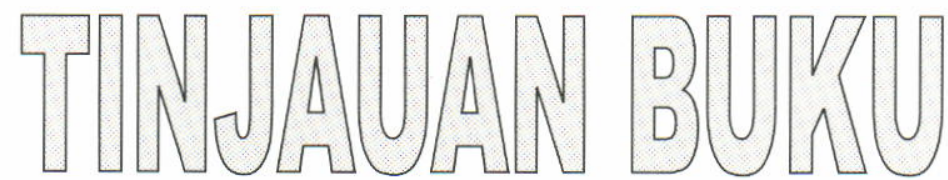

Oleh: Endang Sriyati

Pusat Riset Perikanan Tangkap

\section{PROSIDInG}

\section{Forum Perairan Umum Indonesia $\mathrm{Ke}-1$}

\author{
PEMANFAATAN DAN PENGELOLAAN \\ PERAIRAN UMUM SECARA TERPADU BAGI \\ GENERASI SEKARANG DAN MENDATANG
}

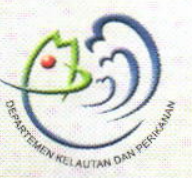

Departemen Kelautan dan Perikanan

Badan Riset Kelautan dan Perikanan

Pusat Riset Perikanan Tangkap

Tahun 2005
Sebagai tindak lanjut dari Forum Perairan Umum Indonesia I tahun 2004 yang diselenggarakan di Palembang Juli 2004, Pusat Riset Perikanan Tangkap telah menerbitkan Prosiding Forum Perairan Umum I. Buku ini mengulas makalah-makalah yang telah dipresentasikan oleh peserta seminar, baik yang bersifat kebijakan maupun yang merupakan hasil penelitian.

Buku setebal 475 halaman dibagi menjadiempat bagian, yaitu:

1. Makalah kunci sebanyak satu judul oleh Menteri Kelautan dan Perikanan.

2. Makalah Utama sebanyak 14 judul yang mengulas berbagai kebijakan di perairan umum dariberbagai sektor.

3. Makalah Penunjang sebanyak 38 judul yang merupakan hasil penelitian di perairan umum dan dipresentasikan pada forum.

4. Makalah Penunjang Lain-lain sebanyak 12 judul yang merupakan hasil penelitian di perairan umum tetapi tidak dipresentasikan pada forum.

Bagi yang berminat untuk mengetahui isi prosiding secara detail, dapat menghubungi: Perpustakaan Pusat Riset Perikanan Tangkap, Jl. Pasir Putih I Ancol Timur Jakarta Utara 14430. Telp. (021) 64711940 Ext. 112; Fax. (021) 6402640; E-mail: library_prpt@indo.net.id. 


\section{JURNAL PENELITIAN PERIKANAN INDONESIA (JPPI) \\ Pedoman Bagi Penulis}

\section{Ruang Lingkup}

Jurnal Penelitian Perikanan Indonesia (JPPI) memuat hasil-hasil riset strategis perikanan tangkap meliputi perikanan laut dan perikanan perairan umum, yang mencakup bidang: sumber daya ikan, oseanografi perikanan, lingkungan perairan, teknologi penangkapan, rehabilitasi lingkungan, dan pengkayaan stok ikan.

\section{Tata Cara Pengiriman Naskah}

Naskah yang dikirim harus asli dan jelas tujuan, bahan yang digunakan, maupun metode yang diterapkan dan belum pernah dipublikasikan atau dikirimkan untuk dipublikasikan di mana saja. Naskah diketik dengan program MS-Word dalam dua spasi dikirim rangkap tiga. Penulis dapat mengirimkan naskah ke Redaksi Pelaksana Jurnal Penelitian Perikanan Indonesia, Pusat Riset Perikanan Tangkap, Jl. Pasir Putih No.1 Ancol. Jakarta Utara 14430, Telp.: (021) 64711940, Fax.: (021) 6402640, E-mail: library prptiondo net i:

Tim Penyunting berhak menolak naskah yang dianggap tidak layak untuk diterbitkan.

\section{Penyiapan Naskah}

- Judul hendaknya tidak lebih dari 15 kata dan harus mencerminkan isi naskah, diikuti dengan nama penulisnya. Jabatan atau instansi penulis ditulis sebagai catatan kaki di bawah halaman pertama.

- Abstrak merupakan ringkasan penelitian dan tidak lebih dari 250 kata. Kata kunci (3-5 kata) harus ada dan dipilih dengan mengacu pada Agrovocs.

- Pendahuluan secara ringkas menguraikan masalah-masalah, tujuan dan pentingnya penelitian. Jangan menggunakan subbab.

- Bahan dan Metode harus secara jelas dan ringkas menguraikan penelitian dengan rincian secukupnya sehingga memungkinkan peneliti lain untuk mengulangi percobaan yang terkait.

- Hasil disajikan secara jelas tanpa detil yang tidak perlu. Hasil tidak boleh disajikan sekaligus dalam tabel dan gambar.

- Tabel disajikan dalam bahasa Indonesia dan Inggris, dengan judul di bagian atas tabel dan keterangan. Tabel diketik menggunakan program MS-Excel.

- Gambar skema, diagram alir, dan potret diberi nomor urut dengan angka Arab. Judul dan keterangan gambar diletakkan di bawah gambar dan disajikan dalam bahasa Indonesia dan Inggris.

- Kesimpulan disajikan secara ringkas dengan mempertimbangkan judul naskah, maksud, tujuan, serta hasil penelitian.

- Daftar Pustaka disusun berdasarkan abjad tanpa nomor urut dengan urutan sebagai berikut: nama pengarang (dengan cara penulisan yang baku), tahun penerbitan, judul artikel, judul buku/nama dan nomor jurnal, penerbit dan kotanya, serta jumlah/nomor halaman. Hanya pustaka yang dikutib perlu dimasukkan dalam Daftar Referens. Sebagai contoh adalah:

Heinen, J.M., D'Abramo, L.R., Robinette, H.R. \& Murphy, M.J. 1989. Polyculture of two sizes of freshwater prawns (Macrobrachium rosenbergi) with fingerling channel cattish (Getalurus punctatus). J. Wordd Aquaculture Soc. 20(3): 72-75.

Collins, A. 1977. Process in acquiring knowledge. In Anderson, R.C., Spiro, R.J. \& Montaque, W.E. (eds.). Schooling and the Acquisition of Knowledge. Lawrence Erlbaum, Hillsdale, New Jersey. p.339-363

Bose, A.N., Ghosh, S.N., Yang, C.T. \& Mitra, A. 1991. Coastal Aquaculture Engineering. Oxford \& IBH Pub. Co. Prt. Ltd., New Delhi. 365 pp.

Untuk sitiran dari Tesis, seperti contoh berikut:

Simpson, B.K. 1984. Isolation, Characterization and Some Applications of Trypsin from Greenland Cod (Gadus morhua). PhD Thesis. Memorial University of New Foundland, St. John's, New Foundland, Canada. 179 pp.

\section{Cetak Ulang}

Penulis akan menerima 25 buah cetak ulang (reprint) secara cuma-cuma. Bagi tulisan yang disusun oleh lebih dari seorang penulis, pembagiannya diserahkan kepada yang bersangkutan.

\section{Komunikasi Singkat}

Naskah yang mencakup aspek yang agak spesifik belum mendalam dengan data dan informasi awal, tetapi dipandang segera untuk dipublikasikan sebagai "Komunikasi Singkat" dengan persetujuan penulis.

Lain-lain

Jurnal Penelitian Perikanan Indonesia menerima sumbangan naskah dari penulis di luar Pusat Riset Perikanan Tangkap dengan ketentuan isinya memenuhi kriteria standar JPPI. 
